FITRAH Jurnal Kajian Ilmu-ilmu Keislaman

Vol. 05 No. 2 Desember 2019

e-ISSN : 2460-2345, p-ISSN: 2442-6997

Web: jurnal.iain-padangsidimpuan.ac.id/index.php/F

\title{
THE IMPLEMENTATION OF CURRICULUM 2013 IN ISLAMIC EDUCATION SUBJECT AT MUHAMMADIYAH PAKEM ELEMENTARY SCHOOL
}

\section{TUKINEM \& HENDRO WIDODO}

Universitas Ahmad Dahlan Yogyakarta

E-mail : kikinuraisyah90@gmail.com \& hendro.widodoUAD@gmail.com DOI: $h$ ttp://dx.doi.org/10.24952/fitrah.v5i2.1602

$$
\begin{aligned}
& \text { ملخص } \\
& \text { تنطلق هذه الدراسة من المشكلات التي تظهر فيما يتعلق بتنفيذ منهج } 2013 \text { للمواد الدراسية ، } \\
& \text { وخاصة في التربية الدينية الإسلامية بالمدرسة الإبتدائية الحكومية المحمدية ، فاكم، والتي لم تتم } \\
& \text { تطلبقها كما هو المتوقع • وأما الأغراض من هذه الدراسة (1) لمعرفة كيفية تنفيذ منهج } 2013
\end{aligned}
$$

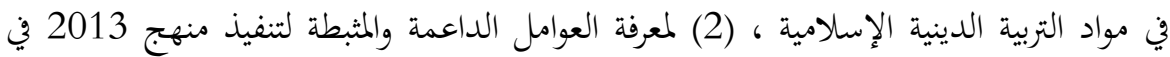

$$
\begin{aligned}
& \text { مدرسة الإبتدئية المحمدية فاكم . طريقة البحث من هذا البحث هي المقابلة غير منظمة ومراقبة }
\end{aligned}
$$

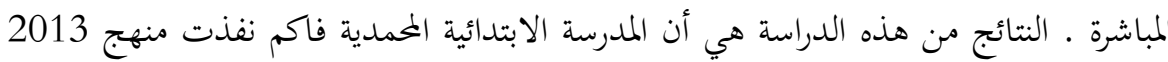

$$
\begin{aligned}
& \text { في التربية الإسلامية ، خاصة في عملية التعلم ، لكن التقدير مايزال بإستخدام تقدير المناهج } \\
& \text { المدرسية. ويرجع ذلك من النقوص الوضوح فيما يتعلق بالأدوات أو التطبيقات المستخدمة في } \\
& \text { تقدير المناهج الدراسية لعام 2013. والعوامل الداعمة لتنفيذ منهاج } 2013 \text { في التربية الإسلامية } \\
& \text { هي المصدر البشرية الكافية ، ووجود معلمين من الشباب والحيوية. العامل المثبط هو عدم توفر }
\end{aligned}
$$

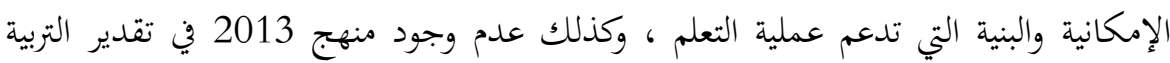

$$
\begin{aligned}
& \text { الإسلامية ـ الاستنتاج من هذه الدراسة هو أن تنفيذ منهج } 2013 \text { في التربية الإسلامية قد تم } \\
& \text { تنفيذه في عملية التعلم بالمدرسة الابتدائية المحمدية فاكم ، في حيئذ أن تقدير الدرس مايزال } \\
& \text { بإستخدام المناهج المدرسية. وهذا لا ينفصل عن العوامل الداعمة والمثبطة التي تصاحب ذلك. } \\
& \text { الكلمات المفتاحية: التنفيذ ، التربية الإسلامية ، المناهج }
\end{aligned}
$$

\section{Abstrak}

Penelitian ini berangkat dari permasalahan yang muncul terkait dengan implementasi kurikulum 2013 mata pelajaran, khususnya Pendidikan Agama Islam di SDN Muhammadiyah Pakem, yang maksimal belum seperti yang diharapkan. Tujuan penelitian ini adalah (1) untuk dapat mengetahui bagaimana implementasi kurikulum 2013 pada mata pelajaran Pendidikan Agama Islam, (2) untuk mengetahui faktor pendukung dan penghambat implementasi kurikulum 2013 di Sekolah Dasar Muhammadiyah Pakem . Metode penelitian ini adalah dengan wawancara tidak terstruktur dan observasi langsung. Hasil dari penelitian ini adalah Sekolah Dasar 
FITRAH Jurnal Kajian Ilmu-ilmu Keislaman

Vol. 05 No. 2 Desember 2019

\begin{abstract}
Muhammadiyah Pakem telah menerapkan kurikulum 2013 dalam Pendidikan Islam terutama dalam proses pembelajaran, tetapi penilaiannya masih menggunakan penilaian kurikulum berbasis sekolah. Ini karena kurangnya kejelasan terkait dengan perangkat atau aplikasi yang digunakan untuk penilaian kurikulum 2013. Faktor pendukung untuk implementasi kurikulum 2013 dalam Pendidikan Islam adalah adanya sumber daya manusia yang memadai, keberadaan guru yang sebagian besar masih muda dan energik. Faktor penghambatnya adalah kurangnya ketersediaan fasilitas dan infrastruktur yang mendukung proses pembelajaran, serta tidak adanya kurikulum 2013 dalam aplikasi penilaian Pendidikan Islam. Kesimpulannya adalah bahwa implementasi kurikulum 2013 dalam Pendidikan Islam telah dilaksanakan di Sekolah Dasar Muhammadiyah Pakem dalam proses pembelajaran, sementara penilaiannya masih menggunakan penilaian kurikulum berbasis sekolah. Ini tidak terlepas dari faktor pendukung dan penghambat yang menyertainya.
\end{abstract}

Kata kunci: implementasi, Pendidikan Islam, Kurikulum

\title{
INTRODUCTION
}

Education from a historical and philosophical point of view has contributed in coloring and becoming a moral and ethical foundation in the process of national identity formation. Education is a variable that cannot be ignored in transforming knowledge, skills and moral values. This is in accordance with the National Education System Law Number 20 of 2003, namely the national education goals written in Chapter II concerning the basis, functions and objectives of national education. The article states that:

"National education works to develop the ability and shape the character and civilization of the dignified nation in educating life of the nation, ..."1 All educational programs at various levels and types of education are designed to achieve these goals. The design of the education program at every level and type of education is called the curriculum. The curriculum has a very important position in education. In fact, curriculum is the key in education, because it deals with determining the direction, content, and process of education. The curriculum is the intention and hope that is written in the form of a program or plan that will be implemented by the teacher in the school. In addition, the curriculum is an educational design that covers all the learning experiences provided for students in schools ${ }^{2}$. According to Sukmadinata ${ }^{3}$, the curriculum is a

1 Republik Indonesia Direktorat Pendidikan Menengah dan Umum, “Undang-Undang Republik Indonesia Nomor 20 Tahun 2003 Tentang Sistem Pendidikan Nasional" (Jakarta: Sekretaris Negara, 2003), https://doi.org/10.1007/s13398-014-0173-7.2.

${ }^{2}$ Arifin, Z. (2011). konsep dan model pengembangan kurikulum. remaja Rosdakarya. 
plan that provides guidance or design in the process of teaching and learning activities. The curriculum is prepared by education experts / curriculum experts, science experts, educators, education officials, and other elements of society. This draft is designed with the aim of providing guidance to implementers, in the process of guiding the development of students, achieving goals that become the ideals of education stakeholders (students, teachers, families, communities) ${ }^{4}$.

The curriculum change is a necessity of the Government through the Ministry of Education and Culture (Ministry of Education and Culture, planning curriculum changes starting in the 2013/2014 academic year. As stated by the Ministry of Education and Culture school-based curriculum changed to the curriculum 2013, precisely on July 15th, 2013 gradually implemented in schools. Curriculum 2013 is also inseparable from the pros and cons of some educators in Indonesia because it raises several problems ${ }^{5}$.

Curriculum 2013 was highlighted by various parties. One of them is in terms of preparation, the curriculum 2013 requires a budget of up to 2.5 trillion. Less optimal socialization to implementers in the field makes teachers mostly experience confusion about the curriculum 2013. ${ }^{6}$ The government considers this curriculum to be heavier than the previous curriculum. The teacher as one of the curriculum actors in the implementation of the curriculum 2013, but only trained a few months to change learning according to the curriculum 2013. In addition to strengthening and supporting teachers, students also need reinforcement and mentoring in developing attitudes and characters emphasized in the curriculum 2013. One of the changes in the curriculum 2013 is the incorporation of subjects. ${ }^{7}$

Muhammadiyah Pakem Elementary School also applies the curriculum 2013 for ISMUBA subjects (Islamic, Muhammadiyah and Arabic Language) especially on Islamic Education subjects. In its implementation Muhammadiyah Pakem Elementary School refers to the national curriculum and Muhammadiyah curriculum which are developed in accordance with the academic climate in the school environment. The thing that underlies this research is the implementation

${ }^{3}$ Sukmadinata, N. S. (2017). Pengembangan Kurikulum Teori dan Praktik. (Mukhlis, Ed.). PT Remaja Rosdakarya.

${ }^{4}$ Sukmadinata, N. S. (2017). Pengembangan Kurikulum...

${ }^{5}$ Abdillah, I. F. (2016). Implementasi Kurikulum 2013 pada Mata Pelajaran Pendidikan Agama Islam di SMP II Puger. Universitas iIslam Negeri Maliki Malang.

${ }^{6}$ Mulyasa, E. (2013). Pengembangan dan Implementasi Kurikulum 2013. bandung: Pt Remaja Rosdakarya

${ }^{7}$ Mulyasa, E. (2013). Pengembangan dan Implementasi.... 
FITRAH Jurnal Kajian Ilmu-ilmu Keislaman

Vol. 05 No. 2 Desember 2019

of curriculum 2013 in Islamic Education subject is only limited to the learning process, while the assessment is still using the school-based curriculum assessment. One reason is that the curriculum 2013 in Islamic Education appraisal has not yet provided clarity as a guide. Therefore, even though the learning process has been using curriculum 2013 but still uses the school-based curriculum assessment.

In the implementation of curriculum 2013 in Islamic Education at Muhammadiyah Pakem Elementary School has several supporting and inhibiting factors. The implementation of curriculum 2013 in Islamic Education is not separated from these two things. Therefore, the researcher is interested in conducting a study entitled "The Implementation of curriculum 2013 in Islamic Education Subject at Muhammadiyah Pakem Elementary School".

Based on the description of the background above, the objectives to be achieved are as follows:

1. to find out the implementation of the curriculum 2013 in Islamic Education subject at Muhammadiyah Pakem Elementary School.

2. to find out the supporting factors and inhibitors of the curriculum 2013 in Islamic Education subject at Muhammadiyah Pakem Elementary School.

\section{METHODS}

This research method is with unstructured interviews and direct observation. The location of this research is Sekolah Dasar Muhammadiyah Pakem who have implemented the curriculum 2013 in Islamic Education, especially in the learning process, but the assessment still uses the school-based curriculum assessment.

\section{THEORY DESCRIPTION}

In this study, the researcher used curriculum theory including the description of curriculum and the concept of curriculum.

1. The description of curriculum

The term curriculum has various meanings formulated by experts in the field of curriculum development since ancient times until today. The meaning of the curriculum is certainly different from one to the other, depending on the point of view and emphasis or emphasis of the experts concerned. 
The meaning of the curriculum according to Oemar Hamalik that the curriculum comes from the Latin "curricule" means the distance that must be traveled by a runner. At that time, the meaning of curriculum is the distance of education time that must be taken by students who aim to get a diploma. ${ }^{8}$ In the new view the meaning of the curriculum is "the curriculum is interpreted to mean all of the organized courses, activities and experiences which pupils have under the direction of the school, whether in the classroom or not". The implications of the above formulation are as follows: ${ }^{9}$

a. The meaning of the curriculum is broad, because the curriculum is not only limited to subjects (courses), but includes all activities and experiences that are the responsibility of the school.

b. According to this view, all extracurricular activities have been included in the meaning of the curriculum.

c. There is no limited curriculum implementation in the classroom, but it is implied outside the classroom, according to the objectives to be achieved.

$\mathrm{d}$. The methods and strategies used by the teacher should be more creative and innovative according to the activities or experiences that will be delivered.

e. The purpose of education is not merely to deliver courses, or fields of knowledge that are structured (subject), but the formation and character development of students and community life skills.

2. The concept of curriculum

The most important concept that needs to get an explanation in curriculum theory is the curriculum concept. According to Sukmadinata (2017) the curriculum concept is divided into three types, namely curriculum as substance, curriculum as a system, and curriculum as a field of study.

The first concept, the curriculum as a substance has the meaning of a series of plans for learning activities of students in schools to achieve the targets to be achieved. The curriculum can also include all formulation documents about objectives, teaching materials, teaching and learning activities, lesson schedules and evaluations.

8 Hamalik, O. (2011). Dasar-Dasar Pengembangan Kurikulum. Bandung: Remaja

${ }^{9}$ Hamalik, O. (2011). Dasar-Dasar Pengembangan.... 
FITRAH Jurnal Kajian Ilmu-ilmu Keislaman

Vol. 05 No. 2 Desember 2019

The second concept, the curriculum as a system is defined as part of the school system, education system and community system. A curriculum system will produce a curriculum arrangement and function to keep it dynamic.

The third concept, the curriculum as a field of study means the field of study of curriculum experts, education and teaching experts. This is done by library studies, conducting various researches and experiments, new things they get to enrich and strengthen the field of curriculum study.

Based on the three curriculum concepts, we as educators have a stake in developing them to stay afloat.

\section{RESULT AND DISCUSSION}

1. The Implementation of Curriculum 2013 in Islamic Education Subject at Muhammadiyah Pakem Elementary School

Before further discussion related to the implementation of the Islamic Education curriculum, the researcher conveyed the vision and mission and the motto of Muhammadiyah Pakem, Elementary School namely as follows:

a. Preparation

Vision, Mision and Motto of Muhammadiyah Pakem Elementary School. All ISMUBA (Islamic, Muhammadiyah and Arabic Language) teachers above hold ISMUBA subjects with an average number of hours of 30 hours per week.

The average number per class is 32 students. The teaching and learning activities for the ABT and SKJ classes are from 6:40 a.m. - 12:30 p.m., UBA classes arrive at UBK from 6:40 a.m. to 2:00 p.m. WIB. To realize the vision, mission and motto, Muhammadiyah Pakem Elementary School prepares a number of teachers according to their respective concentration of expertise.

b. Implementation

1) Habit Program at Muhammadiyah Pakem Elementary School

Learning Islamic Education at Muhammadiyah Pakem Elementary School has implemented the curriculum 2013 with reference to ISMUBA Education curriculum standards at the Muhammadiyah Elementary School level. 
The academic climate of the Muhammadiyah Elementary School begins with the presence of students entering school every day at 6:40 a.m. continued with the habit of Dhuha prayer in the mosque in congregation from classes IA, II B and II C (Ali Bin Abi Talib) to class VI A, VI B, and VI C (Umar Bin Khattab). The names of the class levels in Muhammadiyah Pakem Elementary School are proposed by the Principal and the teachers who are then approved by the Pakem subdistrict Muhammadiyah Foundation. The naming of the class with the name of the companions of the Prophet was intended so that the class could emulate the noble character in accordance with the names of the companions of the Prophet. Habit of the Dhuha prayer led by one of the scheduled children in turn accompanied by Rakanda and Ayunda the teacher alternately, from observing the ablution to the recitation of the prayer after the Prayer of Dhuha. Followed by the letters muroja'ah contained in juz 30, led by one of the Islamic Education teachers until 07.05 WIB, then entered the respective classes of reading Al-Qur'an led by their classroom teachers until 07.15 WIB.

a) BTAQ Program at Muhammadiyah Pakem Elementary School

The BTAQ program is held at Muhammadiyah Pakem Elementary School every new school year, with the following steps:

i. Iqro 'assessment for all new students to find out to what extent the ability to read iqro'. This is done again even though there are preliminary data when testing the creativity of new students with the aim of ensuring that the ability to read iqro 'is in accordance with tajwid.

ii. Grouping students according to their ability to read iqro '(Volumes 1 through vol. 6).

iii. The implementation of BTAQ is conducted every Tuesday, Wednesday and Friday starting at 07:15 - 08:25 WIB.

iv. Teachers at Muhammadiyah Pakem Elementary School have full teaching hours with an average of 32 hours per week so that the school has not been able to assist the BTAQ maximally.

v. The school recruited outside BTAQ teachers by a number of nine teachers to help implementing BTAQ. 
FITRAH Jurnal Kajian Ilmu-ilmu Keislaman

Vol. 05 No. 2 Desember 2019

vi. In the implementation of BTAQ, the school does not want the quantity of reading but prioritizes the quality of reading in accordance with recitation.

vii. During the implementation of BTAQ students and their accompanying teachers have cards for monitoring reading and achievement.

viii. The principle of the BTAQ of Muhammadiyah Pakem Elementary School is the students will not pass to the next volume when at that time he has not been able to read well and correctly in accordance with recitation.

ix. The target of Muhammadiyah Pakem Elementary School BTAQ is one semester, so in the second semester it is hoped that all students will be able to read the Qur'an properly and correctly in accordance with the recitation.

x. Monitoring, which is conducting an evaluation of the implementation of BTAQ every Friday, related to the achievement of reading, problems or obstacles, constraints experienced in the classroom, and others to jointly think of a solution.

Based on the steps to implement the BTAQ program at the Muhammadiyah Pakem Elementary School, it is a step to realize graduates who have morality in accordance with the vision of Muhammadiyah Pakem Elementary School. At the end of the first semester, iqro graduation is held annually for students who have taken iqro from volumes 1 to 6 (qualifying iqro ').

b) Islamic Education Learning at Muhammadiyah Pakem Elementary School

Allocation of learning time and burden of Islamic Education for Muhammadiyah Elementary School is allocated to learning activities which are carried out in the form of face-to-face learning activities of each class is four study hours per week, and cocurricular and habituation activities in the form of deepening learning material by students designed by teachers to achieve competency standards with an allocation of one lesson per week. 
Islamic, Muhammadiyah and Arabic Language (ISMUBA) education is a special feature and an advantage for Muhammadiyah schools. In an effort to continually improve Muhammadiyah's education quality, the Muhammadiyah Central and Secondary Education Council's Central Board developed the ISMUBA education curriculum for Muhammadiyah schools. The development of this curriculum aims to motivate and improve the quality of school excellence, so as to be able to meet the educational needs of a progressing and relevant Muslim generation of gold competencies. The function of ISMUBA is one of the goals of strengthening Al-Qur'an's aqeedah, worship, and morality and literacy, so that the Government issues Character Education Strengthening policies through schools as the role of implementing and optimizing the character of students. In the implementation of the Islamic Education at Muhammadiyah Pakem Elementary School refers to the ISMUBA curriculum structure published by the Muhammadiyah Regional Leadership and Intermediate Education Council (PWM Dikdasmen Assembly) Yogyakarta Special Region in 2017.

c. Assessment (Evaluation)

Regarding the implementation of Islamic Education at Muhammadiyah Pakem Elementary School, the researcher conducted an interview with an Islamic Education teacher at Muhammadiyah Pakem Elementary School, Mr. Shoiful Fahri, S. Pd. I. He said that the curriculum 2013 in Islamic Education had basically been implemented at Muhammadiyah Pakem Elementary School, namely for class I, II, IV, and V. For class III and class VI still using the curriculum 2006. Even though the curriculum 2013 had been implemented, it was limited to the learning process, while the assessment is still using the curriculum 2006 assessment. He added that the curriculum 2013 in Islamic Education assessment lacked of socialization from the Elementary and Secondary Education Council, even though the maker of this application was an IT teacher whose domicile was working in Muhammadiyah schools. So it is ironic that the software for evaluating the curriculum 2013 report cards is one of Muhammadiyah's teachers, but why does the curriculum 2013 in 
FITRAH Jurnal Kajian Ilmu-ilmu Keislaman

Vol. 05 No. 2 Desember 2019

Islamic Education assessment team not exist. This is a material for thought for the Dikdasmen Council and those who are related so that there are software currriculum 2013 in Islamic Education assessments from class I to class VI.

Assessment of Islamic Education in the curriculum 2013 for previous years without using a description, but for this academic year Islamic Education teachers must make a description of KI-3 one description and KI-4 one description. Next, it is deposited to the homeroom teacher for the report card score at the end of this odd semester.

Based on the information above, it has been able to answer the problem formulation as explained above that the implementation of the curriculum 2013 in Islamic Education at Muhammadiyah Pakem Elementary School has been implemented in the learning process, but for its assessment it still uses school-based curriculum assessment. This is because there is no clarity on the device or application that will be used for assessment in accordance with the curriculum 2013 assessment.

2. Supporting and Inhibiting Factors for the Implementation of Curriculum 2013 in Islamic Education

Furthermore, the researcher conveyed the supporting factors and the inhibition of the implementation of the curriculum 2013 in Islamic Education at Muhammadiyah Pakem Elementary School. The following are the supporting factors for the implementation of the curriculum 2013 in Islamic Education at Muhammadiyah Pakem Elementary School:

a. The existence of adequate human resources is that the majority of the teachers are young so they are fast moving and still energetic.

b. Access to implementing learning with IT and environment-based support.

The inhibiting factors for the implementation of the curriculum 2013 in Islamic Education at Muhammadiyah Pakem Elementary School are:

a. Facilities and infrastructure

Facilities and infrastructure that do not support the learning process, while a teacher must use infrastructure or media that support the learning process. 
Based on observations from researchers, the LCD that is owned is only two and the class is eighteen, so the loan must be scheduled so that it does not collide with other teachers.

b. Evaluation and assessment

The scoring system contained in the curriculum 2013 is very complicated, not all teachers understand and understand in depth how the assessment is in the curriculum 2013.

Based on the result of this research, it is known that the application of curriculum 2013 are not maximal yet. It is because of the curriculum is complicated, the educators or teachers are difficult to apply it. For example in preparation, there must be many steps and tools must be prepared, also for evaluation; and it is very complex. The most important think is this school has applied the curriculum, although it is not fully $100 \%$. There are some problems in implementing this curriculum as stated by Retnawati, et.al ${ }^{10}$, the problems are the teachers are getting difficult to apply this curriculum because they donot fully understand about the fully system of assessment and in developing instrument for evaluating students' attitude and authentic assessment. It is also found in this research that made the curriculum is not fully implemented. Moreover, it is also related to what has been found by Abdullah ${ }^{11}$ that showed the teachers' problems are in developing the instrument for assessing students' learning performance and ability. By this, it is known that although the curriculum has been implemented for more than 5 years, there are still many problems to be solved by the teachers, or government in order to make the curriculum applicable to be used in every level and types of education.

${ }^{10}$ Retnawati et al., “ERIC - EJ1086958 - Vocational High School Teachers' Difficulties in Implementing the Assessment in Curriculum 2013 in Yogyakarta Province of Indonesia, International Journal of Instruction, 2016-Jan," International Journal of Instruction, 9, no. 1 (2016): 3348, https://eric.ed.gov/?id=EJ1086958.

11 Abdullah, "Implemenatasi Penilaian Autentik Kuriukulm 2013 Pada Pembelajaran Pendidikan Agama ISlam Di MAdrasah Tsanawiyah Negeri 2 Palangka Raya," FITRAH:Jurnal Kajian Ilmu-Ilmu Keislaman 2, no. 2 (2016): 59-82, http://jurnal.iainpadangsidimpuan.ac.id/index.php/F/article/view/470/pdf_1. 
FITRAH Jurnal Kajian Ilmu-ilmu Keislaman

Vol. 05 No. 2 Desember 2019

\section{CONCLUSION}

Based on the research related to the implementation of the curriculum 2013 in Islamic Education subject conducted at Muhammadiyah Pakem Elementary School, the conclusions can be seen as follows:

1. The implementation of the curriculum 2013 in Islamic Education subject at Muhammadiyah Pakem Elementary School has run smoothly in the learning process, but has not yet reached the assessment stage.

2. In the implementation of the curriculum 2013 in Islamic Education subject experienced several obstacles, namely facilities and infrastructure were less supportive to maximize the application of the curriculum 2013, especially Islamic Education subject. 


\section{REFERENCES}

Abdullah. “Implementasi Penilaian Autentik Kurikulum 2013 Pada Pembelajaran Pendidikan Agama ISlam Di MAdrasah Tsanawiyah Negeri 2 Palangka Raya." FITRAH:Jurnal Kajian Ilmu-Ilmu Keislaman 2, no. 2 (2016): 59-82. http://jurnal.iainpadangsidimpuan.ac.id/index.php/F/article/view/470/pdf_1.

Abdillah, I. F. (2016). Implementasi Kurikulum 2013 pada Mata Pelajaran Pendidikan Agama Islam di SMP II Puger. Universitas iIslam Negeri Maliki Malang.

Abdul Majid. (2007). Perencanaan Pembelajaran Mengembangkan Standar Kompetensi Guru. Bandung: PT Remaja RosdaKarya.

Arifin, Z. (2011). Konsep Dan Model Pengembangan Kurikulum. remaja Rosdakarya.

Departemen Agama RI. (2006). Al-Qur'an dan Terjemahnya. Jakarta : CV. Nala Dana.

Direktorat Pendidikan Menengah dan Umum, Republik Indonesia. "UndangUndang Republik Indonesia Nomor 20 Tahun 2003 Tentang Sistem Pendidikan Nasional." Jakarta: Sekretaris Negara, 2003. https://doi.org/10.1007/s13398-014-0173-7.2.

Retnawati, Heri, Hadi, Samsul, Nugraha, and Ariadie Chandra. "ERIC EJ1086958 - Vocational High School Teachers' Difficulties in Implementing the Assessment in Curriculum 2013 in Yogyakarta Province of Indonesia, International Journal of Instruction, 2016-Jan." International Journal of Instruction, 9, no. 1 (2016): 33-48. https://eric.ed.gov/?id=EJ1086958.

Hamalik, O. (2011). Dasar-Dasar Pengembangan Kurikulum. Bandung: Remaja Rosdakarya.

Imas Kurinasih dan Berlin Sani. (2014). Implementasi Kurikulum 2013: Konsep dan Penerapan. Surabaya: Kata Pena.

Ismet Basuki dan Hariyanto. (2014). Asesmen Pembelajaran. Bandung: PT Remaja Rosdakarya.

Kementerian Agama RI. (2015). Penilaian Proses dan Hasil Belajar Modul VI PLPG.

Keputusan Menteri Agama Nomor 165 Tahun 2014 Tentang Kurikulum 2013 Mata Pelajaran Pendidikan Agama Islam dan Bahasa Arab di Madrasah. 
FITRAH Jurnal Kajian Ilmu-ilmu Keislaman

Vol. 05 No. 2 Desember 2019

Kokom Komalasari. 2013. Pembelajaran Kontekstual: Konsep dan Aplikasi. Bandung: PT Refika Aditama.

Kunandar. 2014. Penilaian Autentik (Penilaian Hasil Belajar Peserta Didik Berdasarkan Kurikulum 2013): Suatu Pendekatan Praktis disertai dengan Contoh, Ed. Rev. Jakarta: Rajawali Pers.

Mulyasa, E. (2013). Pengembangan dan Implementasi Kurikulum 2013. bandung: Pt Remaja Rosdakarya.

Salinan Lampiran Peraturan Menteri Pendidikan dan Kebudayaan Republik Indonesia Nomor 66 Tahun 2013 Tentang Standar Penilaian Pendidikan.

Salinan Lampiran Permendikbud Nomor 104 tahun 2014 tentang Penilaian Hasil Belajar oleh Pendidik pada Pendidikan Dasar dan Pendidikan Menengah.

Sugiono. (2012). Metode Penelitian Pendidikan Pendekatan Kuantitatif, Kualitatif, dan R\&D. Bandung: Alfabeta.

Sukmadinata, N. S. (2017). Pengembangan Kurikulum Teori dan Praktik. (Mukhlis, Ed.). PT. Remaja Rosdakarya.

Sunarti dan Selly Rahmawati. 2014. Penilaian dalam Kurikulum 2013; Membantu Guru dan Calon Guru Mengetahui Langkah-langkah Penilaian Pembelajaran. Yogyakarta: Andi Offset.

Zakiah Darajat. (2009). Ilmu Pendidikan Islam. Jakarta: Bumi Aksara. 